\title{
Romances de la tradición oral jiennense
}

Los materiales que ofrezco a continuación pertenecen a la recogida de romances de tradición oral que en los años 1980 y 1981 llevé a cabo en cuatro pueblos de la provincia de Jaén. El hecho de que gran parte del fruto de este trabajo permanezca inédito ${ }^{1}$ me impulsa a dar a la imprenta aquéllo que considero más importante, con el fin de que pueda ser aprovechado por los investigadores que lo estimen oportuno. Dicha búsqueda romancística, realizada bajo la dirección de Diego Catalán, se efectuó concretamente en los pueblos de Martos, Torredonjimeno, Villardompardo y Jamilena, siendo este último el indagado con más exhaustividad y por tanto el que produjo mayores frutos. Todo el material recogido se encuentra en la Cátedra-Seminario Menéndez Pidal y está constituido por unas seis horas de grabación magnetofónica que, además de romances, contiene coplas, villancicos, etc.; asimismo, allí se conserva la transcripción de los romances registrados y los datos relativos a éstos. Aparte de 41 romances de ciego, fueron 21 los romances de tradición oral más antigua recogidos, éstos, siguiendo la clasificación propuesta por Manuel Alvar ${ }^{2}$, pertenecen a los ciclos «bretón», «carolingio y pseudocarolingio», «novelesco», «de labriegos y pastores» y «bíblico»; ante la imposibilidad de transcribir aquí todas las versiones de esos 21 romances he optado por reproducir sólo nueve de los recolectados, los «novelescos» según dicha clasificación, ya que, además de la importancia de este grupo en general, dentro de él se encuentran dos de especial relevancia por habernos sido recitados por una sola persona, lo cual demuestra su ra-

1 Algunas de las versiones que de La muerte ocultada obtuve en mi trabajo fueron utilizadas en Romancero tradicional, XII, La muerte ocultada, edición y estudio de Beatriz MARISCAL DE RHETT (Madrid: Gredos, 1984-1985). Asimismo, algunas de las versiones de Amón y Tamar se encuentran en José CHECA BELTRÁN, «Vulgata y actualización de contenidos en la tradición oral del romance de Amón y Tamam, Spicilegio Moderno, 21-22 (1987), pp. 52-71.

2 Manuel Alvar, Romancero viejo y tradicional (México: Porrúa, 1971). 
reza, al menos por lo que se refiere a la zona explorada. Estamos hablando de La serrana de la Vera y Las tres cautivas. En efecto, cada uno de los restantes romances nos fueron dichos por varias personas, siendo los más difundidos de entre los «novelescos», por este orden: Hermanas reina y cautiva, La muerte ocultada y La hermana cautiva.

Debo resaltar el dato de que el $90 \%$ de los romances recogidos fueron cantados, y sólo el $10 \%$ restante recitados ${ }^{3}$. Atendiendo a una clasificación temática de los nueve romances que siguen, éstos se incluyen dentro de los siguientes apartados: «cautivos» (3 romances), «esposa desgraciada» (2), «vuelta del esposo» (1), «mujeres matadoras» (2) y «aventuras amorosas» (1), relacionados a continuación según este mismo orden.

La recolección a la que nos estamos refiriendo fue llevada a cabo en la comarca olivarera de Martos, cuya principal fuente de riqueza es precisamente el olivo y los cereales. Así, aparte de algunas mujeres que declararon haber aprendido los romances cuando cosían o bordaban con sus amigas, la mayor parte de los informantes, hombres y mujeres, manifestaron haberlos aprendido en momentos de trabajo, o descanso, relacionados con la recogida de aceituna o con la siega.

Transcribo los textos con las grafías normativas del castellano, si bien los informantes eran yeístas y aspiraban la «s» final y anterior a consonante. Por último, he creído conveniente incluir una breve información general de cada uno de los romances ${ }^{4}$ sin entrar en detalles bibliográficos o eruditos, ya que, como queda dicho, el fin de estas páginas es exclusivamente el de ofrecer unos textos inéditos que consideramos interesante sean conocidos.

\section{LA HERMANA CAUTIVA}

Conocido también con los nombres de Don Bueso, La cautiva, Moralinda. Al volver de los torneos, etc. ${ }^{5}$. La antigüedad de este romance, muy difundido en la tradición oral moderna, queda atestiguada por su

\footnotetext{
3 En efecto, de las 16 versiones que se ofrecen en las páginas siguientes, 15 fueron cantadas por sus respectivos informantes mientras que sólo una fue recitada.

+ Especialmente útiles en este sentido, por incluir para cada romance una síntesis de las investigaciones más destacadas, son los libros de Michelle DéBAX, Romancero (Madrid: Alhambra, 1982), y Pedro M. PIÑero y Virtudes ATERo, Romancero de la tradición moderna (Sevilla: Fundación Machado, 1987).

5 Para los distintos nombres atribuidos a cada romance me baso en Mercedes DIAZ RoiG, El romancero y la lírica popular moderna (México: El Colegio de México, 1976).
} 
presencia actual entre los judíos de Marruecos y oriente. Según Menéndez Pidal ${ }^{6}$, procede, a través de una balada juglaresca perdida, del poema austríaco Kudrun (siglo XIII), cuyo tema triunfó en diversos países europeos, adaptándose en España a su peculiar situación histórica (cautiverio en tierra de moros). Su éxito se debe a poseer una estructura narrativa de gran reconocimiento popular coincidente con la organización odiseica: ausencia $e$ infelicidad-regreso y reconocimiento feliz. Conocido en versiones hexasílabas y octosílabas, las primeras, de más antigüedad, incluyen las circunstancias del prendimiento de la cautiva, desapareciendo éstas en los textos de ocho sílabas que comienzan con el encuentro de Don Bueso y su hermana. Las versiones que ofrecemos aquí, de rima «í-a», pertenecen a este último tipo.

\section{Texto 1 a}

\begin{tabular}{|c|c|c|}
\hline & Qué día tan desgraciado, & día de Pascua Florida, \\
\hline 2 & la reina salió a paseo & se le perdió su hija. \\
\hline 4 & $\begin{array}{l}\text { La reina se ha vuelto loca, } \\
\text { y su hermano Moralejo } \\
\text { y al pasar por un arroyo }\end{array}$ & $\begin{array}{l}\text { el rey llora y suspira } \\
\text { la busca de noche y día, } \\
\text { la vió y no la conocía. }\end{array}$ \\
\hline 6 & $\begin{array}{l}\text { - Apártate mora linda, } \\
\text { que voy a darle a mi caballo }\end{array}$ & $\begin{array}{l}\text { apártate de la linda, } \\
\text { de ese agua cristalina. }\end{array}$ \\
\hline 8 & $\begin{array}{l}\text { - No soy mora, caballero, } \\
\text { me cautivaron los moros }\end{array}$ & $\begin{array}{l}\text { que soy cristiana cautiva, } \\
\text { desde que era pequeñita. }\end{array}$ \\
\hline 10 & $\begin{array}{l}\text {-Si te quisieras venir } \\
\text { - ¿Y los pañuelos que lavo, }\end{array}$ & $\begin{array}{l}\text { aquí en mi caballería. } \\
\text { dónde me los dejaría! }\end{array}$ \\
\hline 12 & $\begin{array}{l}\text { - Los finos y los de Holanda } \\
-i Y \text { mi honra, caballero, }\end{array}$ & $\begin{array}{l}\text { aquí en mi caballería. } \\
\text { dónde me la dejaría? }\end{array}$ \\
\hline 14 & $\begin{array}{l}\text { Yo te juro por mi espada } \\
\text { de no mirarte ni hablarte }\end{array}$ & $\begin{array}{l}\text { que mi pecho va cautivo } \\
\text { hasta los montes de olivas. }\end{array}$ \\
\hline 16 & $\begin{array}{l}\text { Llegando por aquel monte } \\
-¿ \text { Qué suspiras linda mora, }\end{array}$ & $\begin{array}{l}\text { ya suspira la cautiva. } \\
\text { qué suspiras bella linda? }\end{array}$ \\
\hline 18 & $\begin{array}{l}\text {-Suspiro que en este monte } \\
\text { y mi hermano Moralejo }\end{array}$ & $\begin{array}{l}\text { mi padre a cazar venía, } \\
\text { y yo en su compañía, }\end{array}$ \\
\hline 20 & - ¿Qué oigo Virgen del Carm & men, qué oigo Santa María? \\
\hline 22 & $\begin{array}{l}\text { que pensé traer mujer } \\
\text { Ábreme las puertas, padre, }\end{array}$ & $\begin{array}{l}\text { y traigo una hermana mía. } \\
\text { ventana de Santa Lucía, }\end{array}$ \\
\hline 24 & $\begin{array}{l}\text { que repiquen las campanas, } \\
\text { quitarle el luto al palacio } \\
\text { que ha aparecido la reina, }\end{array}$ & $\begin{array}{l}\text { que repiquen noche y día, } \\
\text { y vestirlo de alegría, } \\
\text { esa que no pacía. }\end{array}$ \\
\hline
\end{tabular}

[Versión de Villardompardo (Jaén), cantada por Soledad Garcés Pérez, de 69 años. Recogida por José Checa y Domingo Jiménez, diciempre de 1980.]

6 Ramón Menéndez Pidal, «Supervivencia del Poema de Kudrun», Los godos y la epopeya española (Madrid: Austral, 1956), pp. 89-173. 


\section{Texto $1 b$}

\begin{tabular}{|c|c|c|}
\hline 2 & $\begin{array}{l}\text { Viniendo de los torneos, } \\
\text { había una mora lavando, } \\
\text { - Apártase mora bella, } \\
\text { deja beber mi caballo }\end{array}$ & $\begin{array}{l}\text { pasando por la moraría, } \\
\text { lavando en la fuente fría. } \\
\text { apártase mora linda, } \\
\text { n el agua cristalina. }\end{array}$ \\
\hline 6 & $\begin{array}{l}\text {-Pues mira usted caballero, } \\
\text { me cautivaron los moros }\end{array}$ & $\begin{array}{l}\text { yo soy cristiana cautiva, } \\
\text { el día de Pascua Florida. }\end{array}$ \\
\hline & $\begin{array}{l}\text {-Si te quieres venir, vente, } \\
\text {-Estos pañuelos que lavo } \\
\text { - Los de seda y los de Holanda }\end{array}$ & $\mathrm{da} \quad \begin{array}{r}\text { ¿dónde } \\
\text { en }\end{array}$ \\
\hline & y $\operatorname{los} q$ & el río aba \\
\hline & $\begin{array}{l}\text { Ha montado en su caballo, } \\
-¿ \text { Por qué suspiras mi alma, } \\
\text { - Suspiro porque mis padres }\end{array}$ & $\begin{array}{l}\text { bira. } \\
\text { mi vic } \\
\text { as }\end{array}$ \\
\hline & y $\mathrm{mi} \mathrm{h}$ & en su c \\
\hline & er muier & mía. \\
\hline & que ha aparecido una rosa & \\
\hline
\end{tabular}

Versión de Jamilena (Jaén), cantada por Petrola Jiménez Arroyo, de 55 años. Recogida por José Checa y Domingo Jiménez el 24 de diciembre de 1980.]

\section{Texto $1 c$}

\begin{tabular}{|c|c|c|}
\hline 2 & $\begin{array}{l}\text { Viniendo yo de paseo, } \\
\text { había una mora lavando, }\end{array}$ & $\begin{array}{l}\text { niendo por la morería, } \\
\text { lavando en la fuente fría. }\end{array}$ \\
\hline 4 & $\begin{array}{l}\text { - Apártate mora bella, } \\
\text { voy a darle a mi caballo }\end{array}$ & $\begin{array}{l}\text { pártate mora linda, } \\
\text { de ese agua cristalina. }\end{array}$ \\
\hline 6 & $\begin{array}{l}\text {-Dispense usted caballero, } \\
\text { me cautivaron los moros } \\
\text { - Si te quieres venir, vente, }\end{array}$ & $\begin{array}{l}\text { que soy cristiana cautiva, } \\
\text { el día de Pascua Florida. } \\
\text { conmigo de la morería. }\end{array}$ \\
\hline 8 & $\begin{array}{l}\text {-Y los pañuelos que lavo, } \\
\text { - Los más finos y los de Holand }\end{array}$ & $\begin{array}{l}\text { ¿dónde me los dejaría? } \\
\text { da, aquí en mi caballo irían, }\end{array}$ \\
\hline 10 & $\begin{array}{l}\text { y los que no valen nada } \\
-Y \text { mi honra, caballero, }\end{array}$ & $\begin{array}{l}\text { el río abajito irían. } \\
\text { ¿dónde me la dejaría? }\end{array}$ \\
\hline 12 & $\begin{array}{l}\text { - Te juro bajo mi espada } \\
\text { Al llegar a las olivas la bel }\end{array}$ & $\begin{array}{l}\text { que mi alma va tranquila. } \\
\text { ella mora suspira. }\end{array}$ \\
\hline 14 & $\begin{array}{l}\text { - ¿Por quién suspiras mi alma, } \\
\text {-Suspiro porque mi padre }\end{array}$ & $\begin{array}{l}\text { por quién suspiras mi vida? } \\
\text { era el dueño de esta finca. }\end{array}$ \\
\hline 16 & $\begin{array}{l}\text { - Tu padre ¿cómo se llama? } \\
\text { y un hermano que tenía }\end{array}$ & $\begin{array}{l}\text {-Mi padre se llama usía, } \\
\text { se llama José María. }\end{array}$ \\
\hline 18 & $\begin{array}{l}\text {-Abrid puertas y ventanas } \\
\text { que por traerme una novia }\end{array}$ & $\begin{array}{l}\text { con muchísima alegría, } \\
\text { me traigo una hermana mía. }\end{array}$ \\
\hline
\end{tabular}

[Versión de Jamilena (Jaén), cantada por Pilar Pérez Colmenero, de 63 años. Recogida por José Checa y Pilar Salanueva el 22 de diciembre de 1980.] 


\section{HERMANAS REINA Y CAUTIVA}

Este romance octosílabo de rima «í-a», muy difundido en la tradición oral moderna, se conoce también como Las dos hermanas, Mora y cautiva, Flores y Blancaflor, etc. Según Menéndez Pidal ${ }^{7}$, no se recogió en el siglo XVI porque los editores de entonces no gustaban de este tipo de «romance cuento». Aún así, es un tema antiguo que procede del poema francés Foire et Blanceflor, del siglo XII, pero mientras que éste centra la atención en los amores de los nacidos el mismo día, los textos españoles derivan hacia el reconocimiento de las dos hermanas y la liberación de una de ellas, aunque este desenlace no siempre acaece.

\section{Texto $2 a$}

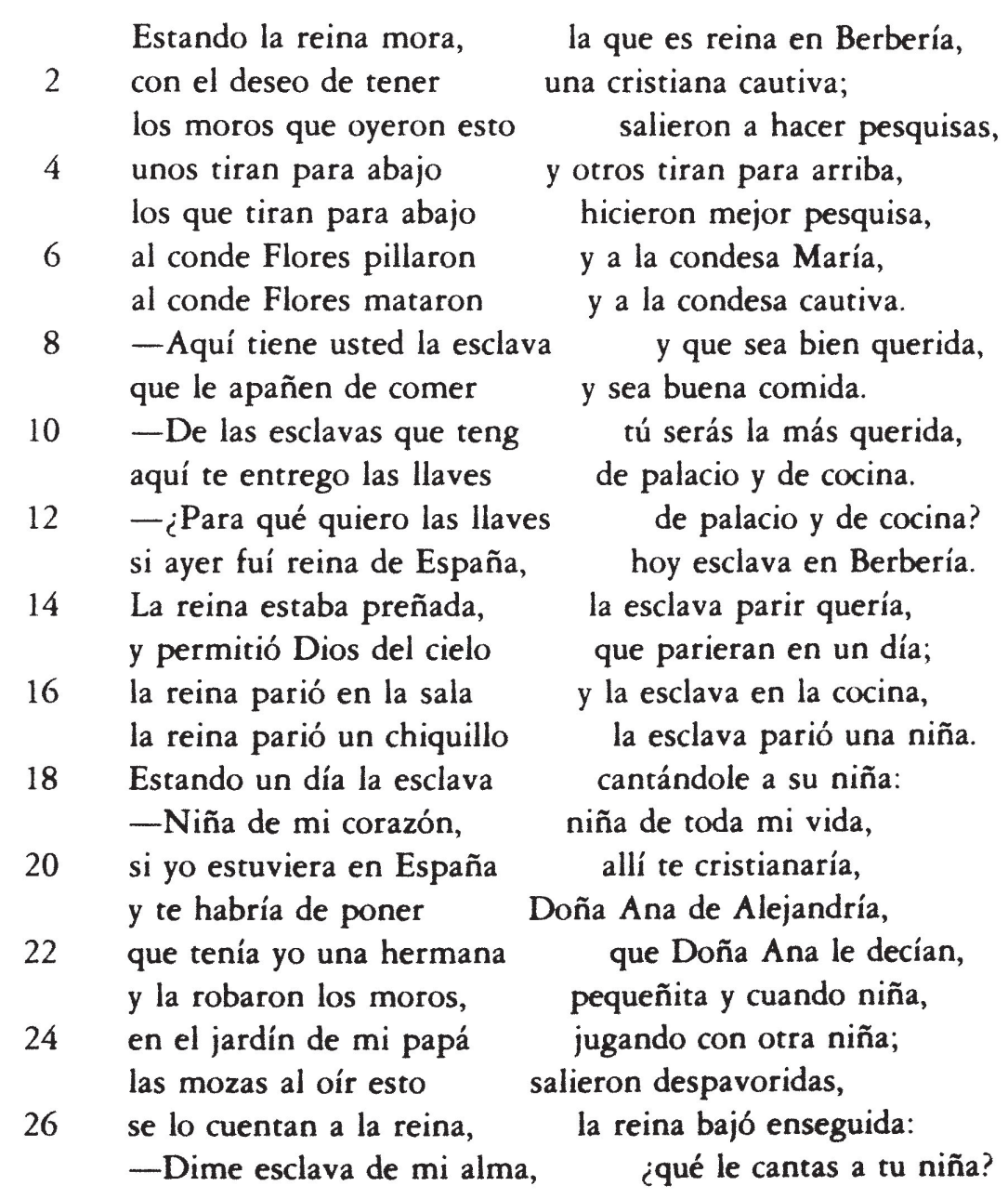

7 Ramón Menéndez Pidal, Romancero bispánico (Madrid: Espasa Calpe, 1968), I, pp. 63-65. 

28 -Sabrás, grandísima reina, los misterios de mi vida, que si estuviera en España allí la cristianaría,
30 y le habría de poner
Doña Ana de Alejandría, que tenía yo una hermana
que Doña Ana le decían,
32 y la robaron los moros, en el jardín de mi papá
34 La reina al oír eso pequeñita y cuando niña, jugando con otra niña.
bajó el grandísimo rey: - ¿quién te ofende vida mía?
$36-$ A mí no me ofende nadie, y mi cuñado es el muerto
$38-i$ Qué quieres que yo le haga
-Que me la pases a España
40 y que le ponga por nombre y que recoja los bienes
al suelo cayó tendida,
que mi hermana es la cautiva
y su hija mi sobrina.
a esa hermana tan querida?
y que cristianes a su niña,
Doña Ana de Alejandría,
que de su padre tenía.

[Versión de Jamilena (Jaén), cantada por Juan Gallardo Nieto, de 80 años. Recogida por José Checa y Juan Checa el 7 de diciembre de 1980.]

\section{Texto $2 b$}

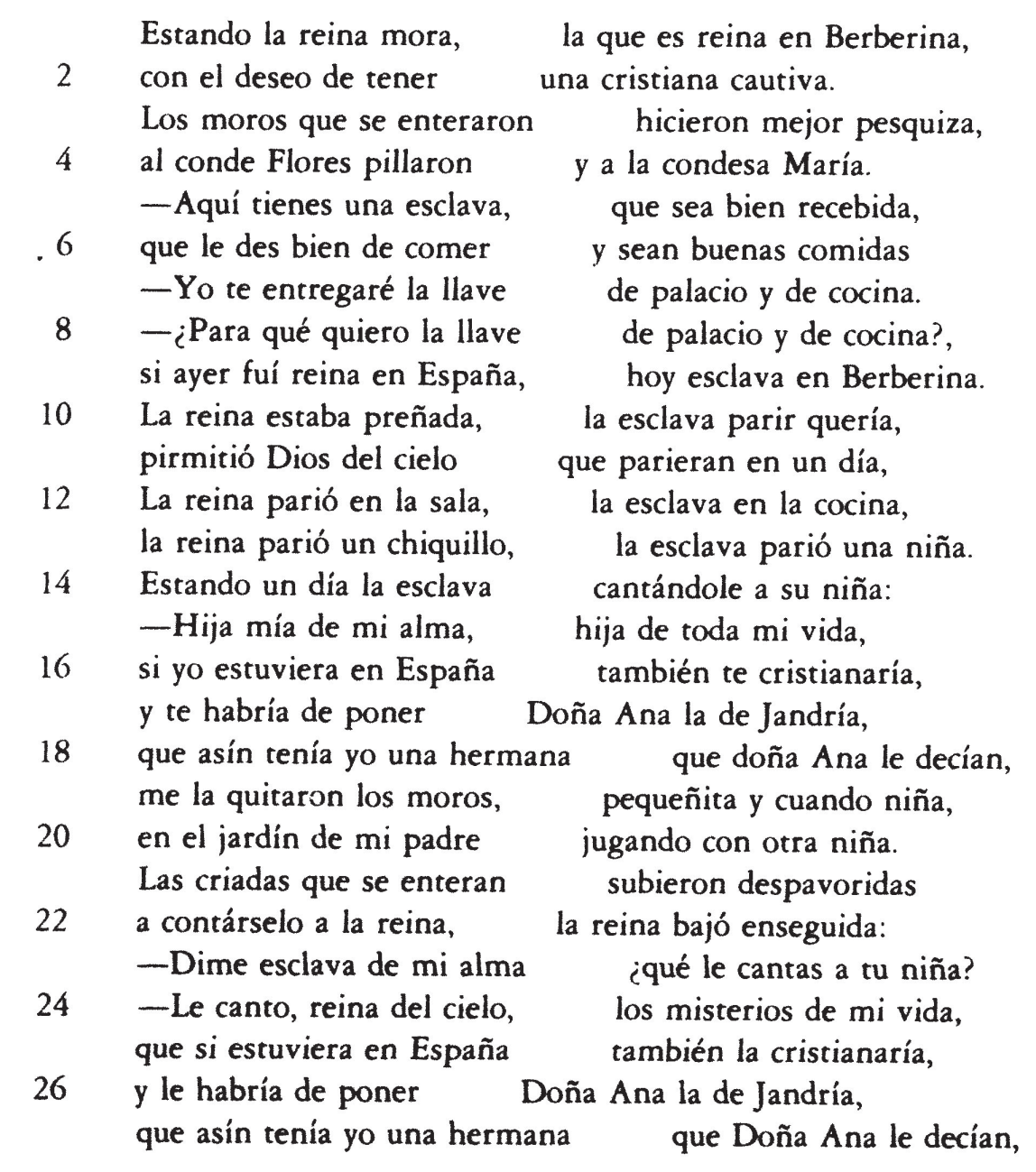


pequeñita y cuando niña.

La reina que oye esto

al suelo cayó tendida,

30 bajó el grandísimo rey:

- ¿Quién te ofende vida mía?

-A mí no me ofende nadie que es mi hermana la cautiva.

$32-i$ Qué quieres que yo te haga con esa hermana querida? -Que me la lleves a España

[Versión de Jamilena (Jaén), cantada por Paula Jiménez López, de 66 años. Recogida por José Checa y Joaquina Checa el 28 de diciembre de 1980.]

\section{LAS TRES CAUTIVAS}

No se conoce el origen de este romance, que ha sido muy poco estudiado y que guarda evidente parecido con el de La hermana cautiva. Hexasílabo, de rima «í-a», a veces presenta un feliz desenlace, motivo por el cual se podría explicar el cambio de rima en el final desgraciado del texto que ofrecemos.

Texto $3 a$

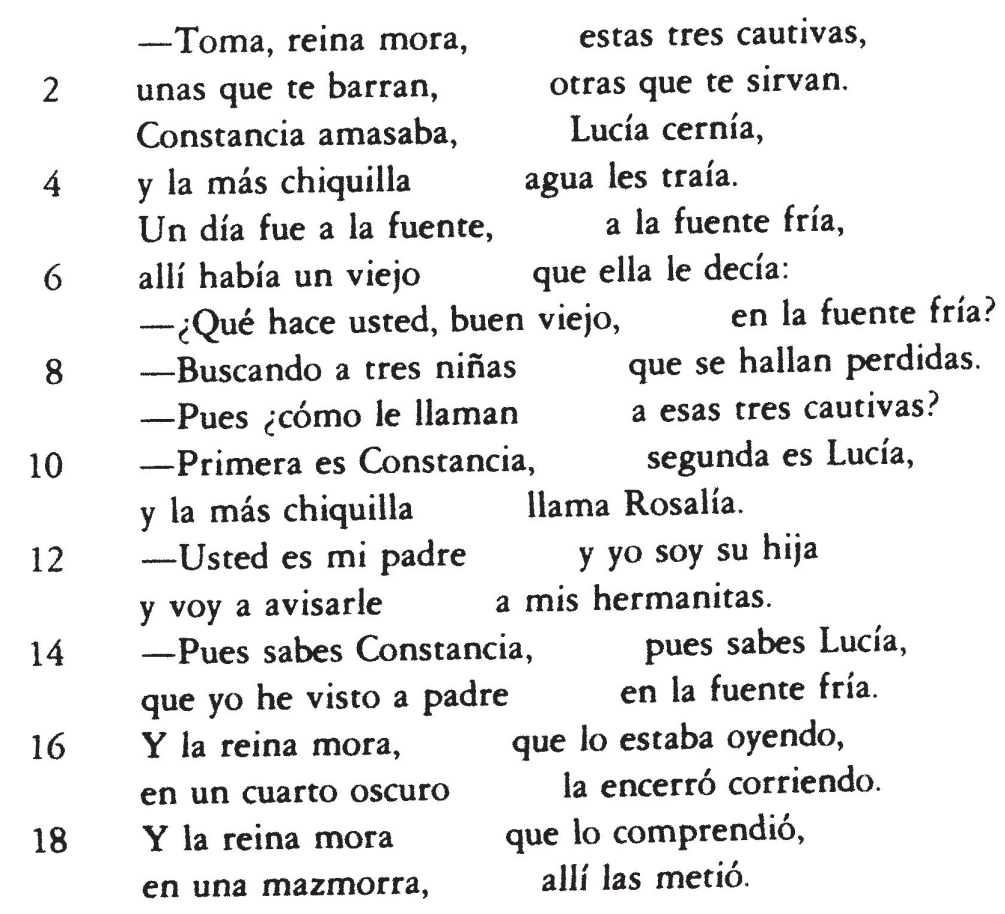

[Versión de Jamilena (Jaén), cantada por Purificación Pérez Bueno, de 47 años. Recogida por José Checa y Joaquina Checa el 4 de enero de 1981.] 


\section{LA MALA SUEGRA}

Se conoce también como Carmela, Doña Algora, Marbella, etc. A pesar de que no fue incluido en las primeras colecciones de romances, se cree en su antigüedad dada su existencia en algunas comunidades judías occidentales. Es uno de los romances más conocidos de la tradición oral actual; gira en torno al conflicto familiar, tan tratado en la literatura universal, madre-hijo-nuera, y contiene determinados tópicos folklóricos y simbólicos. Tal y como sucede en las versiones que aquí ofrecemos (octosilábicas y de rima «a-e») el desenlace es casi siempre trágico, aunque algunos textos acaban con el castigo de la suegra o con la salvación de la madre gracias a las milagrosas palabras del recién nacido.

\section{Texto $4 a$}

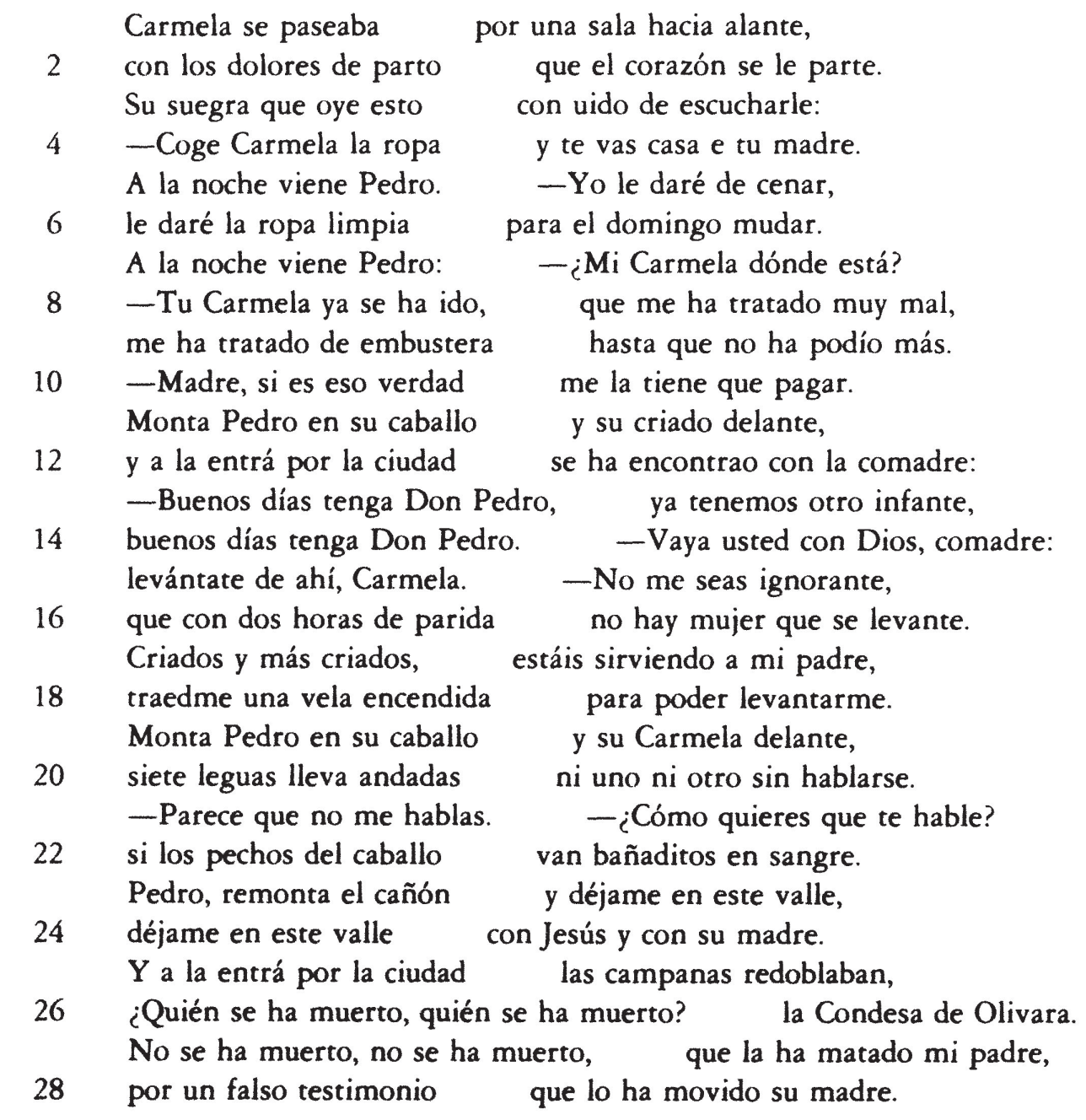

[Versión de Jamilena (Jaén), cantada por Purificación Pérez Bueno, de 47 años. Recogida por José Checa y Joaquina Checa el 4 de enero de 1981.] 


\section{Texto $4 b$}

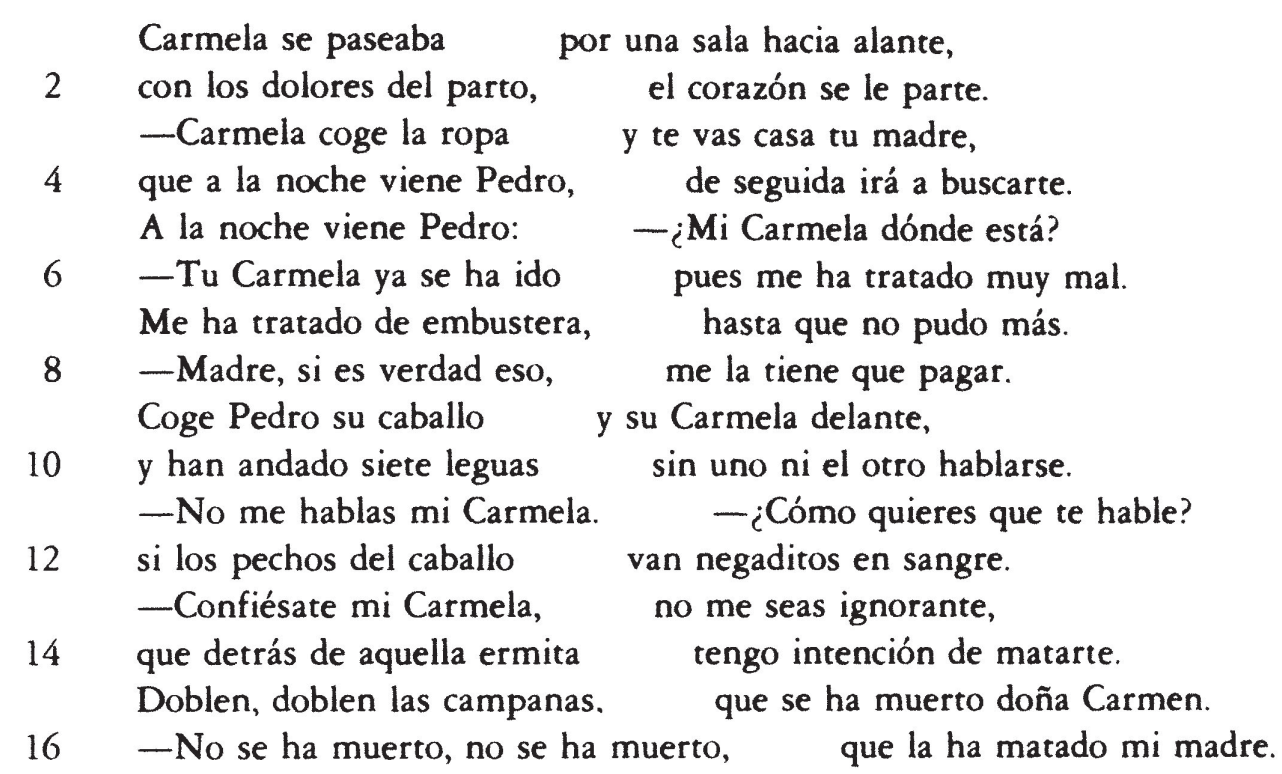

[Versión de Jamilena (Jaén), cantada por Juana Liébana García, de 66 años. Recogida por José Checa y Pilar Salanueva, diciembre de 1980.]

\section{LA MUERTE OCULTADA}

Se conoce también con los nombres de Don Pedro, Doña Alda, Doña Ana, La viudita linda, etc. No se publicó en ninguna de las colecciones antiguas; está muy difundido en la tradición oral moderna habiéndose recogido ya en el siglo XIX. A pesar de no estar resueltos definitivamente los problemas de sus orígenes ${ }^{8}$, parece que es un tema perteneciente al folklore europeo que habría pasado a España a través de la canción francesa Le Roi Renaut. La triple relación madre-hijo-nuera no es conflictiva, como sí lo era en La mala suegra, contribuyendo todos en la defensa de la entidad familiar.

Las distintas formas métricas en que se presenta este romance (hexasílabas y octosílabas) están relacionadas con su contenido: las versiones que aquí ofrecemos son hexasílabas y de rima asonante, en pareados; en ellas la acción avanza hasta el conocimiento de la muerte del marido o, a veces, hasta la muerte de la esposa. Las versiones octosílabas se centran en la ocultación de la muerte del marido; otras versiones hexasílabas, más arcaizantes, comienzan con la lucha del marido contra el Huerco (la muerte).

8 Ibid., I, Pp. 320-323. 


\section{Texto $5 a$}

\begin{tabular}{|c|c|c|}
\hline 2 & $\begin{array}{l}\text { Ya viene Don Pedro } \\
\text { ya viene Don Pedro }\end{array}$ & $\begin{array}{l}\text { de la guerra herido, } \\
\text { a ver a su hijo. }\end{array}$ \\
\hline 4 & $\begin{array}{l}\text { - Yo estoy buena, Pedro, } \\
\text { - Acaba de darme }\end{array}$ & $\begin{array}{l}\text { si tú vienes sano. } \\
\text { buenas razones, }\end{array}$ \\
\hline 6 & $\begin{array}{l}\text { que me está esperando } \\
\text {-Dígame usted, madre, }\end{array}$ & $\begin{array}{l}\text { el rey de las Cortes. } \\
\text { como buena amiga, }\end{array}$ \\
\hline 8 & $\begin{array}{l}\text { ¿qué es ese ruido } \\
\text {-Yo te digo, nuera, } \\
\text { jugar a los naipes }\end{array}$ & $\begin{array}{l}\text { que hay en la cocina? } \\
\text { como buena hija, } \\
\text { como tú sabías. }\end{array}$ \\
\hline 12 & $\begin{array}{l}\text { Toquen las campanas } \\
\text { porque va a salir } \\
\text { Al entrar a misa }\end{array}$ & $\begin{array}{l}\text { con mucha alegría, } \\
\text { la recién parida. } \\
\text { oyó que decían: }\end{array}$ \\
\hline 14 & $\begin{array}{l}\text { - iqué viuda tan guapa, } \\
\text {-Yo le digo, madre, } \\
\text { ¿qué es esas palabras, } \\
\text { - Yo te digo nuera, } \\
\text { mi hijo se ha muerto, }\end{array}$ & $\begin{array}{l}\text { qué viuda tan linda! } \\
\text { como buena amiga, } \\
\text { que a mí me decían? } \\
\text { como buena amiga, } \\
\text { tú no lo sabías. }\end{array}$ \\
\hline
\end{tabular}

IVersión de Jamilena (Jaén), cantada por Juana Liébana García, de 66 años. Recogida por José Checa y Pilar Salanueva, diciembre de 1980.]

\section{Texto 56}

\begin{tabular}{|c|c|c|}
\hline 2 & $\begin{array}{l}\text { Ya viene Don Pedro } \\
\text { ya viene Don Pedro } \\
\text { - ¿Cómo estás Teresa }\end{array}$ & $\begin{array}{l}\text { de la guerra herido, } \\
\text { a ver a su hijo. } \\
\text { de tu feliz parto? }\end{array}$ \\
\hline 4 & - Yo estoy bien Don Ped & tú sí vienes malo. \\
\hline 6 & ¿qué vestido me pongo & para ir a misa? \\
\hline 8 & $\begin{array}{l}\text { Yo te digo nuera, } \\
\text { ponte el de seda negro }\end{array}$ & $\begin{array}{l}\text { omo buena amiga, } \\
\text { que te convenía. }\end{array}$ \\
\hline 10 & $\begin{array}{l}\text { - Yo te digo suegra, } \\
\text { ¿qué eran esas cosas } \\
\text { ¿qué viuda tan guapa, }\end{array}$ & $\begin{array}{l}\text { como buena amiga, } \\
\text { que a mi me decían? } \\
\text { qué viuda tan linda! }\end{array}$ \\
\hline 12 & $\begin{array}{l}\text {-Yo te digo nuera, } \\
\text { mi hijo se ha muerto, }\end{array}$ & $\begin{array}{l}\text { como buena amiga, } \\
\text { tú no lo sabías. }\end{array}$ \\
\hline 14 & $\begin{array}{l}\text { Se ha entrado pal cuarto, } \\
\text { y con un guchillo }\end{array}$ & $\begin{array}{l}\text { corrió la cortina } \\
\text { e quitó la vida. }\end{array}$ \\
\hline 10 & $\begin{array}{l}\text { Toquen las campanas } \\
\text { porque ya se ha muerto }\end{array}$ & $\begin{array}{l}\text { con mucha tristeza } \\
\text { Don Pedro y Teresa. }\end{array}$ \\
\hline
\end{tabular}

|Versión de Jamilena (Jaén), cantada por María Dolores Jiménez Arroyo, de 48 años. Recogida por José Checa y Joaquina Checa el 28 de diciembre de 1980.] 


\section{LAS SEÑAS DEL ESPOSO}

Denominado también La viuda fiel, El soldadito, El Mambrú al revés, La vuelta del esposo, etc. la primera impresión de este popular romance data de 1605. Su tema, odiseico, pertenece al folklore europeo y universal. Según las investigaciones de distintos especialistas, a España habría llegado a través de varios textos medievales franceses. La versión que ofrecemos, octosílaba y de rima en «é», está actualizada con la alusión a la guerra de Melilla, e incluye el reconocimiento de los esposos, secuencia ésta que en algunas versiones no aparece.

\section{Texto $6 a$}

-Soldadito, soldadito, ¿de qué guerra viene usted?
2 -De la guerra de Melilla, ¿qué se la ha ofrecido a usted?
- ¿No ha visto usted a mi marido? que en la guerra está también.
4 - No señora, no lo he visto, ni tampoco sé quién es.
-Mi marido alto y recio, alto y recio como usted,
6 con un lunar en la frente, que también lo lleva usted.
8 -Alza la vista paloma, si me quieres conocer,
yo soy su esposo marido, tú mi querida mujer.

[Versión de Jamilena (Jaén), cantada por María López Moreno, de 63 años. Recogida por José Checa y Juan Checa el 7 de diciembre de 1980.]

\section{LA DAMA Y EL SEGADOR}

Se conoce también como La bastarda y el segador, La bastarda y Doña Inés y el segador. Aunque probablemente existirían, no se conocen versiones antiguas de este romance, octosílabo de rima «a-a», en el que un tema tabú se resuelve merced a una continuada metáfora agrícola. Se difundió en España a través de los cantos de siega. El tema de la seducción de un hombre por una mujer de mayor nivel social es tópico en el folklore universal. La muerte final del segador como consecuencia de la relación sexual habida, parece tener un sentido moralista. Se trata de un romance bastante difundido pero difícil de recoger a causa de su contenido erótico. 


\section{Texto $7 a$}

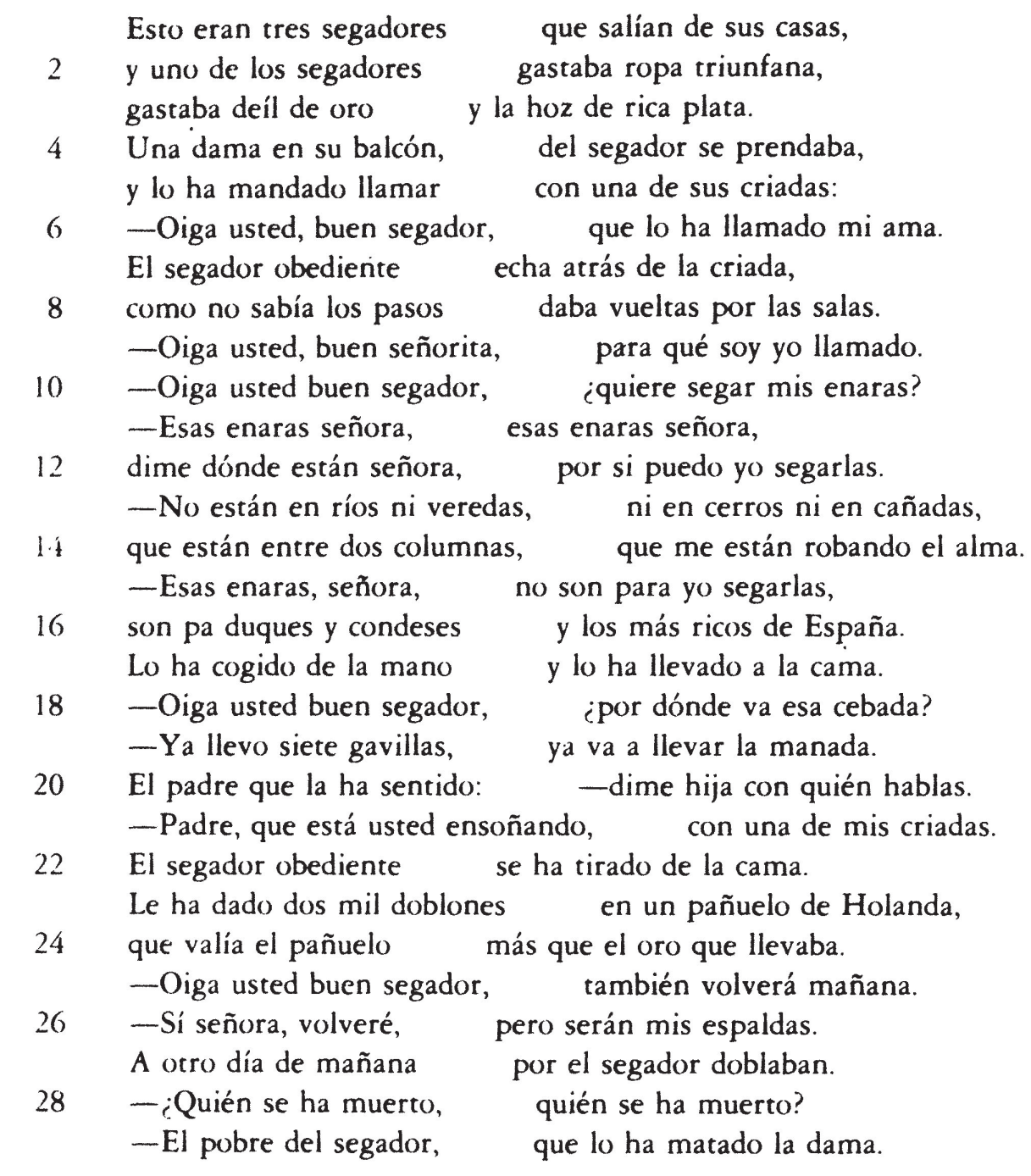

|Versión de Jamilena (Jaén), cantada por Purificación Pérez Bueno, de 47 años. Recogida por José Checa y Joaquina Checa el 4 de enero de 1981.]

\section{Texto $7 b$}

\begin{tabular}{|c|c|c|}
\hline 2 & $\begin{array}{l}\text { Esto eran dos segadores } \\
\text { y uno de los segadores } \\
\text { gasta badiles de oro }\end{array}$ & $\begin{array}{l}\text { que salían de su casa, } \\
\text { gastaba ropa trufana, } \\
\text { y la hoz de rica plata. }\end{array}$ \\
\hline 4 & $\begin{array}{l}\text { Una dama en su balcón, } \\
\text { y lo ha mandado llamar }\end{array}$ & $\begin{array}{l}\text { que al segador le prendaba, } \\
\text { con una de las criadas. }\end{array}$ \\
\hline 6 & $\begin{array}{l}\text {-Oiga usted, buen segador } \\
\text { - Buenos días, señorita, }\end{array}$ & $\begin{array}{l}\text { que lo ha llamado mi ama. } \\
\text { ¿para qué soy yo llamado? }\end{array}$ \\
\hline 8 & $\begin{array}{l}\text {-Oiga usted, buen segador } \\
\text {-Esa cebada, señora, }\end{array}$ & $\begin{array}{l}\text { ¿quiere segar mi cebada? } \\
\text { ¿dónde la tiene sembrada? }\end{array}$ \\
\hline 10 & $\begin{array}{l}\text {-No está en montes ni en } \\
\text { que está en cierta columna, }\end{array}$ & $\begin{array}{l}\text { n vereas, ni en callejones ni en cañas, } \\
\text { a }, \quad \text { que me llega a mi alma. }\end{array}$ \\
\hline
\end{tabular}


12 - Esa cebada, señora, yo no la puedo segarla, que son pa duques y marqueses y los más ricos de España. - Ségala usted, segador, se le dará buena paga. El padre que lo está oyendo: dime hija con quién hablas.

16 - Padre, usted está ensoñando, con una de las criadas. Se tiró los corredores, los salones y las salas.

18 -Oiga usted, buen segador, que se va de sí la paga. le ha dado tres mil doláres en un pañuelo de holanda, 20 que vale más el pañuelo que lo que dentro llevaba. A las doce de la noche redoblaban las campanas,

22 - ¿quién se ha muerto, quién se ha muerto? el segador de la dama.

|Versión de Jamilena (Jaén), cantada por Joaquina Rodríguez Cazalilla, de 57 años. Recogida por José Checa y Juan Checa el 26 de enero de 1981.]

\section{LA SERRANA DE LA VERA}

El contenido de este romance, posiblemente originario de Extremadura, está relacionado con el de La gallarda matadora y La gallarda envenenadora. Sus primeras muestras datan del siglo XVII, época en la que se escribieron las comedias del mismo título de Lope de Vega y de Vélez de Guevara. Según Menéndez Pidal, el romance que tratamos, octosílabo y de rima «a-a», sería el resultado de la evolución de las serranillas medievales. No es frecuente hallarlo en Andalucía. Hasta ahora ha sido poco estudiado; parece ser que J. A. Cid, en un próximo volumen del Romancero tradicional se ocupará de él; dicho crítico, al que hemos facilitado la presente versión, opina que ésta es muy interesante ya que contiene alguna variante insólita en Andalucía, pero habremos de esperar la publicación de u rabajo para conocer más datos.

\section{Texto $8 a$}

Por los montes de Carmona

2 con el pelo muy tendido y una honda de correa

4 Quiso Dios y su fortuna se pasea una serrana, y una escopeta de vara, que al que le tira lo amarra. que con ellos se encontrara

- ¿de quién son todas estas cruces - Son de hombres que he matado, Se agarraron de la mano y le ha puesto de cenar de perdices, codornices y al terminar de cenar - Cántame un romancito,

que hay en mitad de estas vereas? contigo lo mismo hiciera. y se fueron a la cueva, una grandísima cena, y otras aves que vuelan, la reina le dijo: de esos mejores que sepas. 
Cantándole el romancito el mancebo pilló la puerta, tres vueltas le dio al castillo y a la trepá de un cerrillo, -Espérame amante mío, los sesos los echó a la mano y allá ha estado nueve años,

la reina quedó dormida, descalcito y sin zapatos,

oye una voz muy tremenda: que se te olvida una prenda. que vienes hecha una fiera. -Que te espere el gran demonio, que vienes hech
A la volcá de otro cerro lo alcanzó con una piedra, los cascos a la montera, al pie de la esparraguera, y luego a los veinte años se ha vuelto una calavera.

[Versión de Jamilena (Jaén), recitada por Vicente Cazalla Pérez, de 67 años. Recogida por José Checa y Domingo Jiménez el 7 de diciembre de 1980.]

\section{LA DONCELLA GUERRERA}

También denominado El caballero Don Marcos, Don Martinos, Maruxiña, etc. No están claros los orígenes de este argumento tan difundido en muchos países europeos e incluso en China 9 . En nuestro país este tema aparece en algunas obras de los siglos XVI y XVII; existen testimonios de que, como romance, ya era conocido en el siglo XVI. Los desenlaces de las distintas versiones varían según el modo en que es descubierta la protagonista; el final es casi siempre feliz. Los versos son octosílabos y la rima, irregular, en «a-ó».

\section{Texto $9 a$}

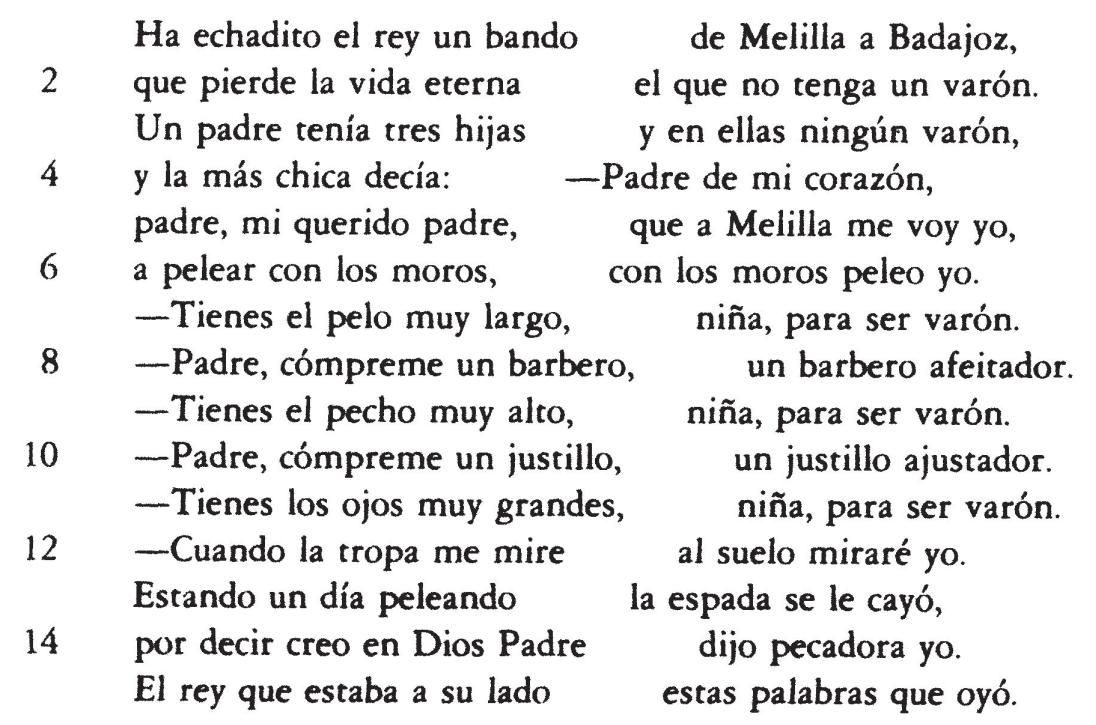

9 Paul BenICHOU, Romancero judeo-español de Marruecos (Madrid: Castalia, 1968), p. 178 
16 -Padre, mi querido padre, que el caballero Don Marcos

18 -Convídala tú, hijo mío, que si ella fuera mujer

20 - Ya la he convidado, padre, yo me tiraba a las flores,

22 Padre, mi querido padre, que el caballero Don Marcos

24 -Convídala tú, hijo mío, que si ella fuera mujer,

26 - Ya la he convidado, padre, yo me tiraba a la orilla,

28 -Convídala tú, hijo mío, que si ella fuera mujer

30 - Ya la he convidado, padre, yo me tiraba a las sedas,

32 - Convídala tú, hijo mío, que si ella fuera mujer

34 - Ya la he convidado, padre, yo me tiraba a la baja,

36 - Convídala tú, hijo mío, que si ella fuera mujer,

-Ya la he convidado, padre, yo apagaba la luz ella iba y la encendía. que el caballero Don Marcos Padre, mi querido padre, que el caballero Don Marcos que yo me muero de amor,

es hembra que no es varón.

al jardín contigo un día, las flores le gustarían.

al jardín a pasear,

ella se tiró a un peral.

que yo me muero de amor,

es hembra que no es varón.

a bañar contigo un día, la orilla le gustaría.

un día conmigo a bañar,

ella se tiró al mitad.

contigo a comprar un día, las sedas le gustarían.

conmigo un día a comprar,

ella se tiró a un percal.

a comer contigo un día, la silla baja cogía.

a comer conmigo un día, ella la más alta que había.

a dormir contigo un día, la luz te la apagaría.

a dormir conmigo un día,

que yo me muero de amor, es hembra que no es varón.

que mi alma ya gozó,

es hembra, que no es varón.

[Versión de Jamilena (Jaén), cantada por Purificación Pérez Bueno, de 47 años. Recogida por José Checa y Joaquina Checa el 4 de enero de 1981.]

\section{Texto 96}

\begin{tabular}{|c|c|c|}
\hline 2 & $\begin{array}{l}\text { El rey ha echadito un bando } \\
\text { que pierde la vida eterna } \\
\text { Un padre tiene seis hijas }\end{array}$ & $\begin{array}{l}\text { dende Francia a Aragón, } \\
\text { el que no tenga un varón. } \\
\text { y en ellas ningún varón, }\end{array}$ \\
\hline 4 & $\begin{array}{l}\text { y la } r \\
\text { ay pa }\end{array}$ & $\begin{array}{l}\text {-Padre } \\
\text { a pelea }\end{array}$ \\
\hline 6 & $\begin{array}{l}\text { a pelear con los moros, } \\
\text { - Tienes el pelo muy largo, }\end{array}$ & $\begin{array}{r}\text { con los moro } \\
\text { niña, par }\end{array}$ \\
\hline 8 & $\begin{array}{l}\text { - Papá traiga usted un barbero } \\
\text { - Tienes los ojos muy grandes, }\end{array}$ & $\begin{array}{l}\text { un barbero afeitador. } \\
\text { niña, para ser varón. }\end{array}$ \\
\hline & $\begin{array}{l}\text {-Cuando me mire la tropa } \\
\text { - Tienes los pechos muy altos, }\end{array}$ & $\begin{array}{l}\text { al suelo miraré yo. } \\
\text { niña, para ser varón. }\end{array}$ \\
\hline & $\begin{array}{l}\text {-Padre, traiga usted un justillo } \\
\text { Estando un día peleando }\end{array}$ & la espada se le cayó, \\
\hline
\end{tabular}



14 y por decir querido padre, El rey que la estaba oyendo
16 de seguida fue a su casa:
dijo pecadora yo,
la palabra le cogió, ay madre, querida madre,
18 que el caballero Don Marcos -padre de mi corazón, que yo me muero de amor, -Pues convídala, hijo mío, que si ella fuera mujer
es hembra, que no es varón.
contigo a correr un día, -Tós los caballeros, madre, atrás te la dejarías.
22 y el caballero Don Marcos no corrían, que trotaban, -Pues convídala, hijo mío, que si ella fuera mujer no corría, que volaba.
al jardín a pasear, -Ya la he convidado, madre, yo me tiraba a las flores, Ay madre, querida madre, que el caballero Don Marcos -Pues convídala, hijo mío,
30 que si ella fuera mujer Y el caballero Don Marcos
32 - Pues convídala, hijo mío, que si ella fuera mujer las flores le han de gustar.

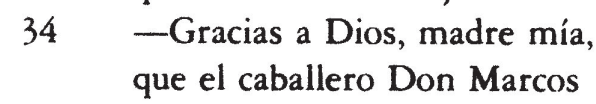

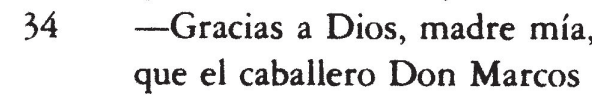 al jardín a pasear, ella se tiró a un peral. que yo me muero de amor es hembra que no es varón. contigo a comer un día, silla baja descogía.
a la más alta que había. contigo a dormir un día, la luz te la apagaría.
que mi alma descansó, es hembra, que no es varón.

[Versión de Jamilena (Jaén), cantada por Paula Jiménez López, de 66 años. Recogida por José Checa y Joaquina Checa el 28 de diciembre de 1980.]

\author{
JosÉ CHECA BELTRÁN \\ Instituto de Filología. CSIC. Madrid
}

Se presentan algunos de los textos de tradición oral que el autor recogió en los años 1980 y 1981 en cuatro pueblos agrícolas de la provincia de Jaén. Del material hallado entonces, hoy depositado en la Cátedra Seminario Menéndez Pidal, ofrece ahora distintas versiones de nueve romances, seleccionados por su común pertenencia al tipo «novelesco». La transcripción de los distintos textos va precedida de una breve exposición en la que se incluyen datos acerca de la antigüedad, procedencia, argumento, etc. de cada uno de los romances.

The author presents in this study some of the texts collected from oral tradition by himself in four agricultural villages of the province of Jaén, during the years 1980 and 1981. The selection of material found at that time, which is at present deposited in the Cátedra Seminario Menéndez Pidal, consists of nine ballads belonging to the novelistic type. They are now offered in several variants. The transcription of the different texts is preceded by a discussion provinding information about the time when the poem developed, as well as about ist origin, plot, etc. 